\title{
PEMELIHARAAN DIRI: PESAN-PESAN ETIK RAJA ALI HAJI KEPADA PENGUASA
}

\author{
Alimuddin Hassan Palawa \\ Institute for Southeast Asian Islamic Studies (IS AIS) \\ Universitas Islam Negeri Sultan Syarif Kasim Riau \\ alimuddin@uin-suska.ac.id
}

\begin{abstract}
Abstrak: Raja Ali Haji meyebutkan babwa penguasa dan pembesar kejaraan harus menjaga tiga unsur kedirian manusia, yaitu unsur al- jism (jasmani, raga atau fisik), al-nafs (nafsani, jïwa atau psikis), al-rūḥ (robani, sukma atau spirit). Ketiga unsur ini merupakan satu susunan kesatuan yang tidak dapat dipisah (integral) dan utub (totalitas) dalam membentukan kedirian manusia. Pertama, dalam pemeliharan rohani Raja Ali Haji menyebutkan penyebab awal terjangkitnya "penyakit" rohani bagi manusia (baca: penguasa dan pembesar kerajaan) dikarenakan "kedatangan beberapa bala' dan susah atau anwū'ul balā'. Hebatnya lagi, setelah mengidentifikasi secara detail peneyebabnya, Raja Ali Haji juga memberikan solusi dalam mengeleminir, menanggulangi atau dalam mengobati penyakit rohani tersbut.Kedua, Pemelibaran jiwa manusia sedemikian penting, sehingga Raja Ali Haji mengungkap jiwa/ hati sebagai "raja" bagi raga manusia. Artinya, kalau bati itu baik pula raganya, sebagaimana kalau raja itu baik akan di rasakan kebaikannya itu oleb masyarakat. Untuk itu, manusia barus senantiasa memelihara dirinya dengan cara menyucikan hatinya (tarkizab al-Nafs). Dan pada gilirannya manusia yang sudah dan akan selalu menyucian diri akan melabirkan akblak baik. Pemeliharan diri dikaitakan dengan akblak yang baik disamakan dengan memeliharan/menjaga nama baik. Ketiga, dalam pemeliharan jasmani/indera-indera ragawi manusia: lidah, mata, telinga, tangan, alat kelamin, kaki dan hati, Raja Ali Haji melakukan dua pendekatan: (i) pendekatan "indra batini" dan (ii) "indera zabiri". Untuk. pemeliharaan indra batini ia menekankan pendekatan sufistik, misilanya memelihara ketujuh anggota badan itu dari laranganlarangan agama. Untuk pemelibaraan indra zabiri adalab lewat olab raga, menjaga pola makan, waktu tidur yang cukup serta mengatur waktu dalam melakukan hubungan seksual.
\end{abstract}

Keyword: Raja Ali Haji, Penguasa, al-Jism, al-nafs, al-rū, Indera

\section{PENDAHULUAN}

Pada pembahasa ini akan diungkapkan pemikiran politik Raja Ali Haji dalam perspektif sufistik dengan istilah "süfi al-siyäsah". "Penciptaan" (tepatnya penggunaan) term "süfi alsiyäsab" yang tidak/belum popular ini dimaksudkan sebagai sandingan dan sekaligus pembeda dalam meneroka perspektif pemikiran politik Islam lainnya, yaitu "falsafah al-siyäsab" dan fiqh al-siyasah. Sekali lagi ditegaskan bahwa fiqh al-siyāsah, "falsafah al-siyāsab" dan "süfi al-siyäsab" dipahami sebagai sebuah "perspektif" dalam memahami pemikiran politik Islam. Selain ini, sebelumnya M. Sirajuddin Syamsuddin menggunakan istilah "trend" dalam pengkajian pemikiran politik Islam (islamic political thought), yaitu "justice trend" (trend hukum, "bureaucratic trend" (trend birokrasi), "philosophic trend" (trend filosofis), "ethical trend" (trend etik).
Mengingat, karena ini hanya sebatas "perspektif' maka term fiqh al-siyasah pun tidak dipahami menjadi terjemahan langsung dari "politik Islam" itu sendiri, sebagaimana dipahami selama ini. Bahwa memperbincangkan politik Islam sama dengan bicara fiqh al-siyasah secara meliputi. Artinya, term figh al-siyasah digunakan untuk memberikan legitimasi keterkaitan dua disiplin itu: berbicara tantang pemikiran politik adalah berbicara tentang fiqh. Pemahaman yang menyebutkan bahwa "bicara politik Islam sama dengan bicara fiqh al-siyäsah secara meliputi" adalah menjadi benar karena kebanyakan sarjana muslim modern kerap sekali, untuk tidak mengatakan melulu, merujuk fiqh sebagai sumber utama, kalau bukan satu-satunya, dari pemikiran politik Islam.

$$
\text { Pada mulanya fiqh al-siyāsah, menurut }
$$

Azra, pada dasarnya adalah upaya "mengawinkan" dua bidang yang berbeda dalam 
tradisi keilmuan Islam, yaitu fiqh dan siyasasa. Namun, sebelum "perkawinan" keduanya telah membawa "cacat bawaan", yaitu term fiqh dan siyasah itu sendiri menyimpan contradiction in terms (perkataan yang mengandung pertentangan). Dengan demikian, keduanya memiliki hubungan yang cukup problematik dan bahkan mungkin "ketegangan" ketika akan "dikawinkan" karena fiqh mempunyai citra dan aura sakral, sementara siyasah mempunyai kecenderungan kuat bersifat profan.

Dalam kesarjanaan Islam klasik selain fiqh ada sumber lain yang seyogyanya dijadikan sumber dalam membincangkan pemikiran politik Islam, yaitu "teologi-filsafat", dan sufisme Islam (tasawuf). Malah "teologi-filsafat" terlebih dahulu membincangkan pemikiran politik Islam, ketimbang fiqh. Pemahaman semacam inilah yang digugat Luthfi Assyaukanie dengan menyatakan bahwa "Fikih bukanlah satu-satunya warisan kesarjanaan kaum muslim yang membicarakan pemikiran politik Islam." Senada dengan ini, menurut Syamsuddin, pemikiran politik Islam -sebagai bagian integral dari sistem pemikiran Islam-- tidak dapat dipisahkan dari pemikiran Islam dalam berbagai aspeknya. Artinya, pemikiran politik Islam banyak berasal dari "kalangan pemikir bidang-bidang lain, seperti mutakallimun, fukaha, failusuf, dan bahkan dari kalangan kaum sufi." Syamsuddin melanjutkan bahwa "Hal ini membawa lahirnya," sebagaimana telah disebut sebelumnya, "beberapa trend dalam pemikiran politik Islam.”

Pada awalnya, sebagaimana terdapat dalam Thamarāt al-Mubimmah, Raja Ali Haji mengungkapkan pemikiran dan teori politiknya dalam perspektif politik-hukum ketatanegaraan (fiqh al-siyäsab). Meskipun demikian, dalam pemikirannya perspektif politik-hukum ini, Raja Ali Haji tetap "meyelinapkan" secara kental ajaran sufistik dan pesan-pesan etika/moral politik. Tambahan pula, pada bagian "Khatam" (penutup) dari Thamarät al-Mubimmah yang justru separoh dari bagian karyanya itu, Raja Ali Haji mengungkapkan pemikiran politiknya dalam "bentuk" nasehat kepada penguasa dan pembesar kerajaan agar memelihara diri dengan pendekatan ajaran-ajaran sufistik dan etika-politik.

Raja Ali Haji meyebutkan bahwa penguasa dan pembesar kejaraan harus menjaga tiga unsur kedirian manusia: jasmani, nafsani, rohani. Di antara ketiganya paling ditekankan oleh Raja Ali Haji untuk dijaga adalah menjaga jiwa (hati). Baginya, jiwa (hati) manusia sedemikian penting, sehingga ia mengungkapnya sebagai "raja" bagi raga manusia. Bahkan ketika mengulas tentang pemeliharan jasmani/inderaindera ragawi manusia: hati, lidah, mata, telinga, tangan, alat kelamin dan kaki, ia lebih menginginkan pemeliharaan bersifat "batini" ketimbang "zahiri". Untuk itu, Raja Ali Haji mengungkapkan sejumlah sikap dan sifat jelek harus dijaga jangan sampai bersemayam dalam hati. Dan itu ia uraikan dengan panjang lebar di akhir Thamarät al-Mubimmah dengan pendekatan, sekali lagi, sufistik dan ajaran moral-politik.

\section{A. Pemeliharaan Ruhani}

Manusia pada dasarnya terdiri dari tiga unsur, yaitu unsur al- jism (jasmani, raga atau fisik), al-nafs (nafsani, jiwa atau psikis), al-rūh (rohani, sukma atau spirit). Ketiga unsur ini merupakan satu susunan kesatuan yang tidak dapat dipisah (integral) dan utuh (totalitas) dalam membentukan kedirian manusia. Akan tetapi, secara umum dan sederhana (simplistis), demi mengikuti pemahaman masyarakat awam, Raja Ali Haji hanya membangi manusia dalam dua unsur: rohani dan jasmani. Meskipun demikian, pada bagian tertentu dalam penjelasannya, ia mengakui secara ekplisit pembagian tiga unsur manusia: ruhani, nafsani dan jasmani tersebut. Kebenaran pernyataan ini terlihat ketika ia menganjurkan dengan tegas "tiada dapat tiada daripada raja-raja" agar memelihara ketiga unsur manusia, yaitu memelihara nyawa (rohani), nama (nafsani) dan badan (jasmanai).

Dalam memelihara diri, menurut Raja Ali Haji, seseorang terlebih dahulu harus mengetahui dirinya. Langkah awal untuk mengetahui diri adalah dengan menyadari bahwa diri terdiri dari "bentuk luar" yang disebut sebagai jasad, dan "wujud dalam" yang disebut sebagai hati dan ruh. Bahkan lebih lanjut, pengetahuan tentang diri merupakan kunci pengetahuan tentang Tuhan. Dengan terilhami hadith yang sangat masyhur di kalangan sufi: "Man 'arafa nafsab faqad 'arafa Rabbab" (siapa mengetahui diri, akan mengetahui Tuhan), Raja Ali Haji tuangkan konsep pengenalan diri tersebut dalam Gurindam Duabelas: Barang siapa mengenal diri Maka telah mengenal akan Tuhan yang Bahari. 
Artinya, pengetahuan tentang (ke)diri(an) adalah kunci awal pengetahuan tentang Tuhan. Pengenalan diri di sini, menurut al-Ghazali (sosok ulama besar "yang [kembali] menghidupkan agama [Islam]" lewat karya agungnya, Ihya a Ulüm al-Din) menjadi rujukan dan panutan utama Raja Ali Haji dalam melahirkan karya-karnyanya), bukannya pengenalan diri secara "lahiri", tetapi lebih pada pengenalan diri secara "batini". Kalau pengenalan diri hanya dimaknai secara lahiriah tidaklah banyak faedahnya, apalagi kalau sampai bermaksud ingin mengenal Tuhan. Karenanya, pengenalan diri secara batiniahlah yang memungkin untuk dapat mengenal Tuhan, sebagaimana diisyaratkan oleh doktrin sufi di atas. Pengenalan diri yang diinginkan Raja Ali Haji sama dengan al-Ghazali, misalnya dengan mengajukan pertanyaan-pertanyaan: siapakah anda (man anta), dari mana anda (min ayna anta), dan akan ke mana anda (ilä ayna anta).

\section{Pengertian Rohani}

Pengertian al-rūh secara sederhana, kata Raja Ali Haji, sama dengan nyawa (atau al-rüh dibahasakan menjadi "roh") yang befungsi sebagai sumber kehidupan manusia. Dengan kata lain, manusia itu hidup karena ruhnya, “.... apabila batal tasyrifnya kepada badan itu matilah manusia itu. Dalam pengertian semacam ini, ruh adalah "jisim yang halus yang terus-menerus hidup." Dengan kata lain, ruh merupakan hakekat manusia yang tidak rusak oleh kematian dan sekaligus sebagai penerima nikmat dan azab di akhirat.

Ruh dalam pengertian tersebut di atas, menurut Raja Ali Haji, tetap menjadi rahasia Ilahi, sementara pemahaman manusia tentang ruh sangatlah dangkal, sedikit dan terbatas. Dalam mempertegas argumentasinya ini, Raja Ali Haji mengutip firman Allah: "yas'alūnaka 'ani al-rūh quli alrüh min amri rabbì wa mà ütìtum min al-ílmi illā qalìlā (dan mereka bertanya kepadamu tentang roh. Katakanlah, roh itu termasuk urusan Tuhan-ku, dan kamu tidaklah diberi pengetahuan melainkan sedikit). Atas keterbatasan pemahaman tentang roh bagi masyarakat awam, karenanya, Raja Ali Haji menyarankan agar tidak mempertanyakan dan membicarakannya, melainkan mengikuti saja pengertian ruh yang telah dijelaskan para ulama terdahulu, seperti ungkapanya: "hendaklah mutala'ah kitab-kitab ahl al-sufi", terutama penjalasan Imam al-Ghazali, sebagaimana termaktub dalam karya monumentalnya, Ihyya Ulüm al-Din.

Pada bagian lain, Raja Ali Haji terkadang juga secara umum dan sederhana mengategorikan ruh sama dengan al-aql, alqalb, dan al-nafs, sebagaimana dilakukan alGhazali. Misalnya, ia menyebutkan bahwa ruh merupakan entitas yang juga mengatahui hakekat segala sesuatu. Maka dalam pemahamahan semacam ini, ruh sama fungsinya dengan akal. Begitu pula, pada bagian lain Raja Ali Haji mengartikan ruh sama dengan al-qalb (hati) yang dapat merasakan kebahagiaan dan kesengsaraan. Ruh, juga merupakan "alat" bagi jasmani (badan/raga) yang menjadi sumber kehidupan dan mobilitas segala aktifitas manusia. Maka ketika ruh mengalami kerusakan akan berimplikasi pada kemudaratan seluruh badan. Karenanya, melihat arti penting eksistensi ruh, ia menyimpulkan bahwa memelihara ruh adalah wajib. Alasan Raja Ali Haji mengatakan bahwa memelihara ruh hukumnya wajib adalah “.... karena jika sakit segala yang tersebut itu membawa kepada membinasakan anggota yang zahir jua."

\section{Jenis dan Obat Penyakit Rohani}

Raja Ali Haji menyatakan bahwa sebab awal terjangkitnya "penyakit" rohani bagi manusia (baca: penguasa dan pembesar kerajaan) dikarenakan 'kedatangan beberapa bala' dan susah atau anw üul balä'. Adapun jenis-jenis anwä̀ul balà' diuraikan Raja Ali Haji dalam Thamarät alMubimmah :

Pertama, pada rezeki yakni sebab kepicikan rezeki yaitu hidup sebab papa; kedua, sebab kedatangan penyakit pada badan dan kepada tubuh; ketiga, sebab bercerai dengan kekasih, sama ada kepada manusia, seperti kematian anak-istri atau sanak keluarga, kaum kerabat dan sahabat handai atau sebab bercerai dengan kekasih, sayang daripada pangkat dan kebesaran dan 
kemulian ...; keempat, dengan sebab kedatangan susah dari pada pihak yang ditakutkan hilang nyawa atau mudharat kepada badan yaitu kesusahan pada pihak seteruan, seperti di dalam permusuhan dan pergaduhan atau lainnya segala pekerjaan yang ditakuti; kelima, sebab kedatangan dihina-hinakan manusia atau barang sebagainya segala pekerjaan yang jatuh dirinya yang jadi menyusahkan dia....

Dari kutipan ini tampak jelas kemahiran Raja Ali Haji dalam mengurai secara rinci tentang jenis-jenis penyebab datangnya anw $\vec{a} u l$ balä (kesedihan, kemalangan dan malapetaka) berupa kemiskinan dan kemelaratan; badan tidak sehat dan penyakit menggerogoti; berpisah dan ditinggal pergi orang dicintai atau hilangnya pangkat dan kedudukan; permusuhan dan akibat fatal yang ditimbulkannya; kehinaan yang menimpa diri disebabkan dari orang lain atau akibat perbutan sendiri.

Hebatnya lagi, setelah mengidentifikasi secara detail, Raja Ali Haji juga memberikan solusi dalam mengeleminir, menanggulangi atau dalam mengobati penyakit rohani yang ditimbulkan oleh anwäul balä. Adapun cara mengobati penyakit rohani ini, menurut Raja Ali Haji, tidak dapat "dengan obat yang zahir, seperti dipegang dan dijabat." Kalimat terakhir ini dapat diinterpretasi bahwa penyakit rohani tidak dapat disembuhkan dengan diagnosa dan resep (obat) dokter. Akan tetapi, penyakit rohani itu hanya dapat diobati secara psikis dengan cara zikir kepada Allah, mendengarkan ayat-ayat al-Qur'an dan Hadith serta "hendaklah sekedudukan dengan orang yang berilmu dan orang-orang saleh". ${ }^{2}$

Lebih lanjut, Raja Ali Haji menyarankan bagi orang tertimpa anwä'ul balä' tersebut agar berdoa memohon pertolongan Allah guna mengobati penyakit roh tersebut setelah menunaikan ritual-ritual keagamaan, khusunya setelah sembahyang tahajjut dan/atau hajat. Dalam menerima anwà' al-balä' yang menimpa tersebut, ia menganjurkan agar sesorang berbaik sangka, berpikir positif dan optimis kepada Allah,

${ }^{1}$ Lihat, Raja Ali Haji, Thamarāt alMuhimmah, 42-43.

${ }^{2}$ Raja Ali Haji, Thamarāt al-

Muhimmah, 43. seperti ungkapnya: "hendaklah berbaik sangka kepada Allah Ta'ala sebab hikmahnya tiada kita ketahui." Dalam menerima cobaan, di samping mengupayakan penyembuhannya, hendaknya dihadapi dengan ridha, "tidak berkeluh kesah dan mengadu kesana kemari," bersikap penuh kesabaran serta tawakkal kepada Allah. Mengingat, sembari Raja Ali Haji melandasi seruannya dengan kandungan firman Allah, "Allah mengasihi orang sabar dan meluaskan orang tawakkal." ${ }^{3}$ Dengan begitu, Allah akan memberikan balasan lebih baik, pahala besar bagi orang bersabar dan bertawakkal di dalam menghadapi cabaan-Nya. Anugerah dan pahala bagi orang sabar dan tawakkal akan diperolah di akhirat kelak, dan juga di dunia ini, ${ }^{4}$ termasuk anugerah penghapusan dari dosa-dosa.

Kemudian, Raja Ali Haji menyebutkan sejumlah nabi dengan kisahnya masing-masing yang seyogyanya diteladani prihal kesabaran, ketabahan dan penyerahan diri meraka pada Allah dalam menghadapi cobaan demi tugas menyempaikan misi kenabihan (risälah alnubinwah) dari Ilahi. Adapun nabi-nabi yang dimaksud, yaitu Nabi Ya'qub;Nabi Ayyub, Nabi Musa, dan Nabi 'Isa, serta Nabi Muhammad yang telah mendapat anugerah "keuntungan" dan keberhasilan dan pahala dari Allah berkat kesabaran dan ketabahan menghadapi cobaan dalam mengemban misi dan amanat dari Allah. Dalam menghadapi cobaan dan ujian dari Allah demi menegakkan kebenaran dan kebaikan, Raja Ali Haji mengajurkan agar penguasa mencontoh dan meneladani keridhaan, kesabaran dan ketawakkalan nabi-nabi tersebut. Dengan begitu, Allah akan memberikan balasan dan pahala yang lebih baik dan banyak kepada penguasa, sebagaimana Allah telah menganugerahkan kepada nabi-nabi-Nya.

\section{B. Pemeliharaan Nafsani}

\section{Tazkiyah al-Nafs: Antara Rūh dan Jasd}

Manusia adalah makhluk yang, menurut Raja Ali Haji --sama dengan pendirian teolog Islam (mutakallimin) mengenai teori penciptaan-diciptakan dari ketiadaan (al-ijäd min al-'adam atau

3 Raja Ali Haji, Thamarāt alMuhimmah, 44.

4 Raja Ali Haji, Thamarāt alMuhimmah, 44. 
creatio ex nibilo). ${ }^{5}$ Ia menyatakan, “.... "Manusia" yaitu "makhluk" yang dijadikan Allah Subhanahu wa Ta'ala daripada tiada kepada ada." " Pandangan teolog (mutakallimin) tentang konsep penciptaan yang dianut oleh Raja Ali Haji (baca: teologi Asy'ariyah) ini bertentangan secara diameteral dengan pandangan filosuf Muslim, khususnya tentang keqadiman alam.

Di antara ketiga unsur, yaitu: unsur rüḥ, nafs dan jasd, unsur penciptaan kedirian manusia yang paling "hakiki dan sejati" adalah al-nafs (nafsani, jiwa atau psikis). Al-nafs pada diri manusia dalam kajian filosifis memiliki dua dimenasi, yaitu natiqah dan bah imiyah. Al-nafs dengan dua demensinya itu berada dan sekaligus "terombang ambing" antara dua pengaruh dan dorongan baik (positif) dari al-Rüh (rohani, sukma atau spirit); dan pengaruh dan dorongan buruk (negatif) dari al-jism (jasmani, raga atau fisik). Dalam pengertian ini, representasi perwujudan al-nafs dalam diri manusia adalah alqalb (arti harfiahnya "bolak-balik"). Al-Qalb (hati) adalah cerminan bagi perbuatan baik dan buruk manusia: kalau baik hatinya baik pula manusianya; kalau rusak hatinya, rusak pula manusianya. Karenanya, Allah menjadikan hati sebagai ukuran penilaian pada diri manusia, ${ }^{8}$ bukannya pada

${ }^{5}$ Q.s. Maryam [ 19]: 67.

${ }^{6}$ Raja Ali Haji, Kitab Pengetahuan Bahasa, 27.

${ }^{7}$ Hadith Nabi Muhammad saw.: "Inna fĩ al-jasd muḍqah idhā șaluhat șaluhat aljasd kulluh wa idhā fasadat fasadat al-jasd kulluh alā wa hiya al-qalb." ("Sesungguhnya di dalam tubuh manusia itu ada segumpal daging, apabila ia baik, maka baiklah seluruh tubuh itu, tetapi apabila ia rusak, maka akan rusak pula seluruh tubuh itu. Segumpal daging tersebut adalah hati.") (Hadith riwayat dari al-Nu'man ibn Basyir. Hadith riwayat Bukhari dan Muslim [Muttafaq 'Alayh]).

${ }^{8}$ Hadith Nabi saw yang sangat masyhur tentang niat, terdapat pada urutan pertama dalam kitab hadis al"Arbaīn, adalah: "Innamā a'māl bi al-niyah" ("Sesungguhnya amal itu tergantung niat"). Di akhir hadis ini Rasul Allah menandaskan bahwa sesiapa yang hijrah kerena Allah dan Raasul-nya maka hijrahnya bagi Allah bentuk rupa dan penampilannya, ${ }^{9}$ tetapi kemuliaan seseorang tergantung takwa dalam hatinya. Begitu pula, Allah menjadikan hati sebagai tumpuan untuk memberikan hukum kepada manusia yang tertanam dalam niatnya. ${ }^{10}$ Al-Qalb (hati) yang "terombang-ambing" tersebut berada di antara dua kutub yang masingmasing mempengaruhinya, yaitu kutub al-rub (rohani) dan kutub al-jasd (jasmani). Kalau al-qalb dengan dimensi jiwa natiqah (insāniyah) dekat atau mengikuti pengaruh dan kehendak al-rüh, kedirian manusia (nafs) akan menjadi baik, dan terangkat derajat kemanusiaanya (ah san takwim). ${ }^{11}$ Sebaliknya, kalau al-qalb (hati) dengan dimensi jiwa bah imiyah (h iwañiyah) dekat, terus-menerus mengikuti pengaruh dan kehendak negatif al-jasm (raga), kedirian manusia (nafs) akan menjadi buruk dan terjatuh derajat kemanusiaannya (asfala säfilìn). ${ }^{12}$

dan Rasul-Nya. Akan tetapi, sesiapa yang hijrah karena wanita yang akan dinikahinya maka hijrahnya sesuai dengan apa yang diniatkan.

${ }^{9}$ Hadith Nabi saw.: "Inna Allāh lā yanz̦uru ilā șūrikum wa amwālikum wa lā kin yanz̧uru ilā qulūbikum wa a'mālikum". ("Sesungguhnya Allah tidak melihat bentuk tubuhmu dan juga bukan hartamu, tetapi Allah melihat hatimu dan amal perbuatanmu.") (HR. Muslim melalui Abu Hurayrah).

10 Firman Allah: "Allah tidak menghukum kamu disebabkan sumpahmu yang tidak dimaksud (untuk bersumpah), tetapi Allah menghukum kamu disebabkan (sumpahmu) yang disengaja (untuk bersumpah) oleh hatimu. Dan Allah Maha Pengampun lagi Maha Penyantun." (Q.s. al-Baqarah [3]: 225).

${ }^{11}$ Firman Allah: "Sesungguhnya Kami telah menciptakan manusia dalam bentuk yang sebaik-baiknya." (Q.s. al-Ṭın [95]: 4).

${ }^{12}$ Firman Allah: "Kemudian Kami kembalikan dia ke tempat yang serendahrendahnya (neraka)." (Q.s. al-Tin [95]: 4-5. Bahkan manusia semacam ini kalau terusmenurus menjatuhkan derajat kemanusiaannya(asfala sāfilīn), pada gilirannya, ia bisa sama seperti binatang 
Al-Qalb (hati) dengan dimensi natiqah (insāniyah) yang mengikuti pengaruh dan kehendak al-rüh inilah yang menjadi locus (tempat bersemayamnya) Nur Ilabi (Cahaya Tuhan), sehingga hati manusia itu menjadi nürāni (hati yang bersifat cahaya [terang]). Hati nurani semacam ini dapat mengenal yang benar dan salah (nilai logis), baik dan jahat (nilai etis) dan indah dan jelek (nilai estetis). Bahkan hati semacam ini, menurut al-Ghazali, ibarat cermin bisa menyikap yang tersembunyi. ${ }^{13}$ Dalam kaitan ini maka wajar kalau Rasul Allah saw. berpesan: "istafti qalbak" (mintalah fatwa pada hatimu). Sebaliknya, al-Qalb (hati) dengan dimensi jiwa bah imiyah (biwāniyah) mengikuti pengaruh dan kehendak negatif al-jasm (raga) inilah yang tidak bisa lagi memancarkan Nur Ilabai (Cahaya Tuhan), sehingga hatinya tidak lagi "nürāni" (bersifat cahaya), tetapi hatinya berubah menjadi "Z ulmāni" (bersifat gelap).

Manusia yang "kelam hatinya" (Z ulmāni), menurut Raja Ali Haji, tidak mampu mengenal lagi benar dan salah (nilai logis), baik dan jahat (nilai etis) dan indah dan jelek (nilai estetis). ${ }^{14}$ Pada tahap berikutnya, hati semacam ini memandang bahwa kesalahan (yang diperbuat) sebagai kebenaran; kejahatan (yang dilakukan) sebagai kebaikan; dan kejelekan (yang dikerjakan) sebagai keindahan. Hati manusia seperti ini benarbenar telah buta, dan bahkan pada gilirannya hati mereka dibutakan oleh Allah. Pada akhirnya, manusia seperti ini lupa kepada Allah dikarenakan oleh hawa nafs atau syaitan. Dan Allah pun akan membuat mereka lupa pada diri mereka sendiri. Hati semacam ini, meminjam istilah al-

bahkan bisa lebih sesat dari binatang ( $k$ a alan'ām bal hum aḍl). Q.s. al-A'raf [6]: 179.

${ }^{13} \mathrm{Al}$-Ghazali mengatakan bahwa: “.... yang lebih menakjubkan lagi, hatinya memiliki jendela yang terbuka ke arah dunia ruh yang tidak kasat mata; kadangkadang bisa ia dapatkan isyarat tentang kebenaran masa depan. Hatinya ibarat cermin yang memantulkan segala sesuatu yang tergambar di lawh al-mahfūz...." Lihat, al-Ghazali, Kimia Ruhani untuk Kebahagian Abadi (Jakarta: Serambi, 2007), 18.

Bahasa, 193.
Ghazali, ibarat cermin terbalik yang "menolak" cahaya, dan itu adalah hati orang kafir.

Dalam menuju dan meraih kembali puncak kesempurnaan diri yang sudah terperosok ke lembah kenistaan dan kehinaan, manusia mutlak melakukan tarkiyyah al-nafs (penyucian diri). Sedemikian penting penyucian diri itu, sehingga menjadi salah satu tugas penting dan utama dari kenabian (risälah al-nubuwwab). Manusia sebagai pribadi juga dituntut menyucikan dirinya lewat jibād al-nafs atau mujähadah al-nafs, yaitu mengerahkan segenap daya-upaya dan kemampuan untuk mengendalikan, menghilangkan dan menyucikan penyakit yang bersemayam dalam jiwa. Manusia yang menyucikan dirinya adalah demi untuk (kebahagian) dirinya sendiri. Allah memberikan jaminan bahwa sesunggunya orang yang menyujikan diri akan merahi keberuntungan. Sebaliknya, seseorang yang (tetap) mengotori dirinya berarti mengantarkan dirinya pada kerugian.

Dalam proses tarkiyyah al-nafs itu, menurut Nurcholish Madjid, ada tiga jenjang perjuangan pribadi harus dilakukan. Pertama, jenjang nafs al-ammārah bi al-su', yaitu berjuang mengalahkan dorongan "nafsu amarab bi al-su", yang senantiasa menggugah dan mengarahkan manusia sampai terprosok kejurang kejahatan dan lembah kemaksiatan. Kedua, jenjang nafs allawwāmah, yaitu membangun kesadaran disertai penyesalan akan kejahatan diri, "nafsu lawwämah". Ketiga, jenjang nafs al-mut ma'innah, yaitu menggapai kebahagian surgawi pada kehidupan akhirat dengan jiwa damai dan tenang dalam keadaan räd iyah mard iyyah antara dirinya dengan Allah.

\section{Esesnsi Eksistensi Manusia: Labora Ergo Sum}

Manusia yang sudah dan akan selalu menyucian diri akan melahirkan berakhlak baik (etika dalam makna universal). Dalam doktirn Islam perbaikan akhlak menjadi alasan utama misi keberadaan manusia pada umumnya, dan keberadaan nabi-nabi, dan Nabi Muhammad saw. pada khususnya. Karenanya, esensi eksistensi manusia diukur, dalam pandangan Islam, sangat tergantung dari akhlaknya yang dimanifestasikan dalam amal-amal saleh. Rasul Allah saw. menyatakan bahwa kebanyakan manusia 
masuk surga karena taqwa dan akhlak baik (al-taqwà wa hausn al-kbulüq). Menurut Nurcholish Madjid, Islam tidak terlalu menekankan prinsip "cogito ergo sum" (aku berpikir, maka aku ada), sebagimana dianut oleh filosuf rasionalis, Rene Descartes [bapak filosuf modern Barat]. ${ }^{15}$ Begitu pula, konsep Islam tentang manusia tidak sama dengan, misalnya pernyataan Andre Gide [intelektual Prancis, 1869-1951], "Saya merasa, maka saya ada"; dan ungkapan Albert Camus [intelektual Prancis, 1913-1960], "Saya memberontak, maka saya ada."

Konsep Islam tentang esensi eksistensi manusia adalah menganut prinsip "labora ergo sum" (Saya beramal, maka saya ada). Artinya, dalam Islam esensi, ukuran dan bentuk keberadaan (mode of existence) seseorang lebih ditentukan oleh amalperbuatannya. ${ }^{16}$ Jadi bukan yang lainnya, semisal ilmu (meskipun amal yang akan dilakukan meniscayakan adanya ilmu sebelumnya), dan bukan pula iman (meskipun amal dan ilmu meniscayakan landasan keimanan sebelumnya). Artinya, kendatipun dalam Islam antara amal, ilmu dan iman tidak dapat dipisahkan, tetapi amal tetap menjadi "ukuran real" keberadaan manusia di dunia ini. Kalau iman dan ilmu saja tidak menjadi "ukuran real" keberadaan manusia, apalagi kalau wajah dan harta. Nabi Muhammad saw. menegaskan: "Inna Allab lä yanzuru ila șuwarikum wa amwälikum wa lakin yanz̧uru ilā quīibikum wa a'mälikum" (Sesungguhnya Allah tidak melihat bentuk luarmu dan bukan pula hartamu, tetapi Allah melihat hatimu dan amal perbuatanmu). ${ }^{17}$ Esensi eksistensi semacam ini ditegaskan dalam ajaran Islam bahwa manusia hanya mendapatkan sesuatu yang diusahakan. Pada bagian lain, Allah berfirman: "Sesungguhnya kamu hanya diberi belasan menurut apa yang kamu kerjakan."18

${ }^{15}$ Lihat, Nurcholish Madjid, Islam, Doktrin dan Peradaban, 418.

${ }^{16}$ Nurcholish Madjid, Islam, Doktrin dan Peradaban, 418.

${ }^{17}$ H.R. Muslim dari Abu Hurairah.

${ }^{18}$ Q.s. al-Taḥrīm [66]: 7.
Dalama pada itu, kalau seseorang berbuat baik berarti ia berbuat baik bagi dirinya sendiri, dan kalau berbuat jahat berarti ia telah berbuat jahat bagi dirinya sendiri. ${ }^{19}$ Seseorang yang mengerjakan amal baik akan mendapat sebutan/nama terpuji (pahala) dan pada gilirannya memperoleh imbalan yang baik pula. Sebaliknya, seorang beramal jahat akan mendapat sebutan/nama terhina (dosa) dan pada gilirannya mendapat balasan yang jelek pula. ${ }^{20}$ Manusia memiliki kebebasan untuk memilih dua jalan yang telah ditentukan Allah: "Wa badaynābu alnajdayn" (Dan Kami telah kepadanya dua jalan). ${ }^{21}$ Artinya, manusia sendirilah yang menentukan: kalau berbuat baik ia akan dipuja; atau kalau berbuat jahat ia akan dihina. Dalam "Syair Nasehat" yang menjadi "epilog" dalam Thamarāt al-Mubimmah, Raja Ali Haji menyebutkan bahasa puitis:

Jalan kehidupan ditunjuke.ean

Berkebun berladang disukakan

Berbuat baik dipujakan

Berbuat jahat dibinakan.

Untuk itu, dalam menjaga/memelihara nama baik, menurut Raja Ali Haji, sama pentingnya memelihara dan perpegang teguh pada agama. Dengan kata lain, orang yang memegang teguh agama berarti orang bersangkutan telah mengukir nama baiknya. Sebaliknya, orang yang tidak berpegang pada agama, maka tidak memiliki nama baik. Dalam Gurindam Duabelas Raja Ali Haji menuturkan dengan indahnya:

\section{Barangsiapa tiada memegang agama \\ sekali-kali tiada boleh dibilang nama.}

Dalam pandangan Raja Ali Haji memelihara agama dan nama (baik) sangat penting dan utama. Walau kita dalam kemiskinan dan menjadi rakyat biasa, menurut pengakuan Raja Ali Haji, tidak masalah, asalkan kita mampu memelihara agama dan nama (baik). Sebaliknya, kalau kita tidak bisa memelihara kedua itu maka tidak ada gunanya kita berumur panjang, dan karenanya, ia tandaskan, kita sama saja dengan binatang:

$$
{ }^{19} \text { Q.s. al-Isra'[17]: 7; al-Jāthiyah [45]: }
$$

15.

$$
\begin{aligned}
& { }^{20} \text { Q.s. Fusșilat [41]: } 46 . \\
& { }^{21} \text { Q.s. al-Balad [90]: } 10 .
\end{aligned}
$$


Syahdan yang kita pegang selama ${ }^{2}$ ini, biaralah kita jadi orang miskin atau jadi orang kecil asal jangan kita cacat kepada agama dan nama. Karena apabila orang ${ }^{2}$ tiada memelihara yang dua perkara itu, tiada guna panjang umur di dunia karena sama juga dengan binatang." 22

Umur panjang tiada artinya, demikian ungkap Raja Ali Haji, kalau tanpa menorehkan nama baik lewat prestasi dan amal saleh. Dengan melakukan amal saleh yang bermamfaat bagi sesama manusia, maka sepeninggalannya (setelah wafat) ia akan dikenang oleh orang lain karena (jasa) nama baiknya, seperti kata pribahasa manusia mati meninggalkan nama. Sebaliknya, manusia yang tidak melakukan amal saleh dan tidak memelihara nama baiknya, menurut Raja Ali Haji berdasarkan kutipan di atas, kedudukannya sama dengan binatang. Bahkan dalam kondisi tertentu, ketika manusia tidak mempergunakan potensi yang dimiliki, seperti panca indera, akal dan hati, al-Qur'an memandangnya "balhum adal " (bahkan lebih sesat), jauh lebih rendah dan hina daripada binatang. Manusia yang lalai semacam ini menjadi menghuni utama neraka jahannam.

Bukankah binatang "dikenang"
(dibutuhkan) orang karena sesuatu yang bermanfaat dan berouna pada binatang untuk keperluan manusia, seperti kulit untuk harimau dan gading untuk gajah, sebagaimana ungkapan pribahasa: "harimau mati meninggalkan belang" atau "gajah mati meninggalkan gading". Harimau diperlukan orang karena kulit belangnya yang bermanfaat; dan gajah dibutuhkan orang sebab gadingnya yang berguna. Lalu, kalau manusia seyogyanya dikenang oleh sesamanya lantaran jasa baik atau amal salehnya. Karenanya, manusia yang paling baik yang paling bermamfaat bagi manusia (khayr al-nās yanfa'u li al-nās).

Oleh sebab itu, apabila seorang penguasa ingin mendapat predikat baik (nama baik), menurut Raja Ali Haji, hendaknya menunjukkan sikap-sikap yang baik dan melakukan perbuatanperbuatan yang terpuji selaras dengan tuntunan agama. ${ }^{23}$ Menurutnya, sejelek-jelek sebutan (asmä al-sayyi'ab) atau seburuk-buruk akhlak (akbläq al-

${ }^{22}$ Putten dan Al-Azhar, Di Dalam Berkekalan Persahabatan, 43.

${ }^{23}$ Raja Ali Haji, Thamarāt alMuhimmah, 47. mazmümah) bagi seorang penguasa adalah sebutan zalim, bodoh, lalai, dan penakut. Dan di antara keempat sifat tercela ini yang, menurut Raja Ali Haji, paling hina dan keji disandang oleh seorang penguasa adalah sebutan zalim. ${ }^{24}$ Menurut Raja Ali Haji kata "zalim" secara etimolgi (lughawr) berati "kelam" (gelap-gulita). Kata ini berasal dari kata "Zalima, yazlimu, zulam (fahu) zaālimun, yaitu isim masdar. Sedangkan pengertian zalim secara terminologi (istilăh) dan syara', menurutnya adalah: “... dengan makna aniaya, yaitu melakukan atas orang bukan dengan sebenarnya, sama ada pada hukuman atau kelakukan yang menyalahi al-Qur'an dan Hadith dan Ijma'; sama ada pada nyawa dan badan orang atau pada harta benda orang atau pada kemaluan orang.." 25

Kemudian, Raja Ali Haji menjelaskan makna zalim dengan membagi dua, yaitu zalim pada diri sendiri dan zalam pada orang lain:

"Syahdan adalah pekerajaan zalim itu ada dua bahagian: pertama, menzalimi dirinya; kedua, mezalimi orang lain. Adapun menzalimi dirinya, seperti mengerjakan ia akan pekerjaan yang membawa mudharat kepada akalnya atau kepada badannya, seperti dikerjakannya dengan dirinya berbuat maksiat atau melelahkan dirinya dengan permainan yang sia-sia atau makan minum ia yang memberi mudharat kepada akal dan badannya atau mensia-siakan umurnya dengan tiada mengerjakan yang kebajikan, itulah menzalimi dirinya. Adapun menzalimi orang lainnya, maka yaitu terlebih maklum seperti yang telah disebutkan pada makna zalim itu." 26

Pada jenis kezaliman yang disebut pertama, Raja Ali Haji memberikan uraian relatif panjang dengan serangkai contoh-contoh. Penjelasan itu dirasanya penting karena pemahaman masyarakat awam tentang zalim terhadap diri sendiri masih kurang "maklum". Untuk itu, ia menjelaskan segala perbuatan yang dapat menimbulkan kemudaratan pada tubuh, akal dan melakukan kemaksiatan adalah bagian

24 Raja Ali Haji, Thamarāt alMuhimmah, 49.

${ }^{25}$ Raja Ali Haji, Thamarāt alMuhimmah, 49-50.

${ }^{26}$ Raja Ali Haji, Thamarāt al-

Muhimmah, 50. 
dari perbuatan zalim terhadap diri sendiri. Berbeda dengan zalim terhadap orang lain, Raja Ali Haji berpendapat bahwa masyarakat "terlebih maklum seperti yang telah disebutkan pada makna zalim itu."

Pada galibnya, kezaliman pada diri sendiri dilakukan oleh setiap orang baik rakyat maupun penguasa; dan kezaliman pada orang lain secara spesifik dilakukan oleh penguasa atas rakyat. Agaknya, kezaliman yang disebut terakhir ini lebih berbahaya karena menimpa orang lain (jadi korban kezaliman); dan sekaligus menjadi sulit untuk mencegahnya karena yang melakukan kezaliaman itu adalah orang yang mimiliki otoritas. Karenanya, Rasul Allah saw. memerintahkan, sepertinya tidak peduli siapapun orangnya, agar seorang muslim menolong saudaranya baik yang menzalimi maupun yang dizalimi. ${ }^{27}$ Perintah Rasul Allah ini merupakan bagian dari penghormatan terhadap harkat dan martabat manusia sebagai makhluk yang tidak boleh menindas dan tidak boleh pula ditindas. ${ }^{28}$

Sebaliknya, sebaik-baik sebutan (asmä' alhusnâ) atau semulia-mulia akhlak (akbläq almaḥmüdah) bagi penguasa adalah adil, cerdas, rajin dan berani. Di antara keempat itu yang paling mulia dan terpuji bagi seorang penguasa, menurut

${ }^{27}$ Hadith Nabi: "Q̄āla Rasūl Allāh șallallāhu 'alaih wa sallam: "Unz̧ur akhāka żāliman aw maẓlūman." Faqāla rajl: "Yā, Rasūl Allāh. Anz̧urhu malūman, fakayfa anz̧arhu zōāliman?" Faqāla: "tamna'hu 'an al-z̧ālim, fakadhālika naẓruka iyyāhu." "Rasulullah bersabda: "tolonglah saudaramu yang (berbuat) zalim dan dizalimi". Maka seorang lelaki bertanya, "Ya, Rasulullah, Saya dapat menolongnya jika ia dizalimi. Akan tetapi, bagaimana saya menolong seseorang yang berbuat zalim?" Rasulullah menjawab: "Kamu harus mencegahnya dari perbuatan zalim, dengan demikian kamu telah menolongnya." (Hadis dari Anas diriwayatkan Bukhari dan Muslim). Hadith-hadith ini dikutip dari Muhammad Asad, The Principles of State and Government in Islam (Kuala Lumpur: Islamic Book Trust, 2001), 33.

${ }^{28}$ Firman Allah: ".... Kamu tidak boleh menindas, dan tidak boleh pula ditindas." (Q.s. al-Baqarah [2]: 279).
Raja Ali Haji, adalah sifat adil. ${ }^{29}$ Karenanya, seperti telah disebutkan sebelumnya, ia menjadikan sifat "adil" sebagai salah satu syarat utama dan penting bagi pengangkatan penguasa, sebagaimana telah disebutkan pada bagian terdahulu.

\section{Pemeliharaan Jasmani}

Dalam pemikiran politik Raja Ali Haji, sebagaimana telah disebutkan di awal, bahwa salah satu syarat seorang untuk menjadi penguasa adalah keharusan mempunyai integritas indera bersifat fisik atau kesempurnaan anggota tubuh (akmāl al-jism). Adapun anggota tubuh yang dimaksud oleh Raja Ali Haji adalah mata, telinga, lidah, tangan, alat biologis (kelamin), dan kaki serta hati dalam pengertian fisik. Akan tetapi, pada kenyataan setelah seseorang menjadi penguasa Raja Ali Haji memaknai integritas indera bersifat batini (rohani). ${ }^{30} \mathrm{Ia}$ mengindentifikasi anggota tubuh ini, sebagaimana ia dapatkan dari kitab-kitab Imam al-Ghazal, ${ }^{31}$ sebagai "anggota yang tujuh" yang berkaitan dengan balasan dan hukuman yang akan diperoleh dalam kehidupan eskatologis: surga dan neraka. Artinya, kalau ketujuh anggota tubuh itu dipelihara dengan baik di dunia, maka manusia akan selamat di akhirat.

Dalam Kitab Pengetahuan Bahasa, Raja Ali Haji menyebutkan dengan merujuk kepada karya ulama, khususnya karya Imam al-Ghazali: "Syahdan tersebut di dalam beberapa kitab Imam Hujjatul Islam Ghazali dan lainnya, barangsiapa yang memelihara anggota tubuh yang tujuh, maka tertutuplah pintu neraka yang tujuh pula, yakni tiadalah ia masuk dari salah satu dari pada neraka yang tujuh itu adanya." ${ }^{32}$ Selanjutnya, Raja Ali Haji menambahkan ".... Maka barang siapa bersungguh-sungguh memeliharkan dia maka

29 Raja Ali Haji, Thamarāt alMuhimmah, 49.

${ }^{30}$ Raja Ali Haji, Kitab Pengetahuan Bahasa, 78-79

${ }^{31}$ Lihat, al-Ghazali, Bidāyah alHidāyah, 64.

${ }^{32}$ Raja Ali Haji, Kitab Pengetahuan Bahasa, 78. 
terbukalah pula pintu surga yang tujuh adaya intaha." 33

Pernyataan Raja Ali Haji tentang "tujuh anggota tubuh" dikaitkan dengan kehidupan akhirat, khususnya dengan tujuh pintu di neraka, seperti dikutip di atas, nyata sekali diambil dari, sebagaimana diungkapnya senditi: “.... tersebut di dalam beberapa kitab Huijah al-Islam Imam alGhazali...," ${ }^{34}$ khususnya Ihyā Ulüm al-Din, dan Bidāyah al-Hidayah. ${ }^{35}$ Begitu pula, Raja Ali Haji mendasarkan pernyataan bahwa hubungan antara tujuh anggota badan dan tujuh pintu neraka pada firman Allah: "(Neraka) Jahannam itu mempunyai tujuh pintu. Tiap-tiap pintu (telah ditetapkan) untuk golongan yang tertentu dari mereka."

Sementara itu, kaitannya dengan kehidupan di dunia ini, bagi menusia secara umum, apalagi bagi penguasa khususnya, kesempuranaan fisik senantiasa menjadi penting untuk diperhatikan dan dipelihara. Kalau pada sebagian dari tujuh anggota tubuh manusia itu sakit, ungkap Raja Ali Haji, akan "memutuskan beberapa pekerjaan". ${ }^{36}$ Karenanya kesehatan fisik, seperti mata (penglihatan), telinga (pendengaran) dan kesempurnaan fisik lainnya, seperti tangan dan kaki menjadi sangat penting dan bahkan, sebagaimana telah disebutkan sebelumnya, dijadikan sebagai salah satu persyaratan bagi pengangkatan seorang penguasa. Artinya, kalau seseorang penguasa tidak memiliki kesempurnaan fisik secara lahiri, misalnya buta --dalam konsepsi pemikiran politiknya yang sangat ideal, seperti pemikiran politik sunni pada umumnya-- Raja Ali Haji menyatakan bahwa orang semacam itu tidak dapat diterima sebagai penguasa.

Raja Ali Haji memang sangat mementingkan integritas inderawi yang harus dimiliki oleh seorang penguasa. Dalam memaknai integritas inderawi itu, ia melihatnya dalam dua pendekatan, yaitu pendekatan "indera batini" dan pendekatan "ind era lahiri. Dari kedua

Bahasa, 79

${ }^{33}$ Raja Ali Haji, Kitab Pengetahuan Bahasa, 78.

${ }^{34}$ Raja Ali Haji, Kitab Pengetahuan

35 Lihat, al-Ghazali, Bidāyah alHidāyah, 64.

36 Raja Ali Haji, Thamarāt al-

Muhimmah, 44 pendekatan ini, sepertinya, ia lebih menekankan makna integritas inderawi pada pengertian "batini" ketimbang pada pengetian "lahiri". Pernyatan terakhir ini dilegitimasi oleh solusi yang ditawarkanya dalam pemeliharan dan pengobatan anggota tubuh tersebut. Pada akhirnya, ia menawarkan dua pendekatan yang solutif, yaitu pendekatan indera-batini dan pendekatan inderalahir akan diungkapkan berikut ini.

\section{Pendekatan Indera-Batini}

Sebelum memelihara jasmani terlebih dahulu seseorang harus mengenal dirinya. Pengenalan pada diri di sini maksudkan, menurut al-Ghazali, sebagimana telah diungkap sebelumnya, bukanlah pengenalan diri dalam makna "lahiri", tetapi lebih pada pengenalan diri secara "batini". ${ }^{37}$ Dengan begitu, pemeliharan jasmani lewat pendekatan indera-batini ini lebih berorientasi dan sekaligus terilhami oleh ajaranajaran sufistik (tasawuf) yang bersumber dari alQur'an dan Hadith Nabi, sebagaimana ungkapnya: "Dan hendakalah peliharakan dia daripada segala kejahatan hati seperti yang tersebut di dalam beberapa kitab karangan ulama yang besar-besar, istimewa pula di dalam alQur'an dan di dalam Hadith." 38

Pemeliharan jasmani (anggota tubuh) lewat pendekatan ini tidak dimaksudkan pemeliharan secara fisik (ragawi), tetapi pemeliharan yang bersifat psikis (kejiwaan). Berikut ini akan dijelaskan tentang pemeliharan jasmani dalam pendekatan indera-batini dalam pandangan Raja Ali Haji dalam berbagai karyanya yang diawali oleh Gurindam Duabelas dan kemudian dipertegas dan dielaborasi secara kalaboratif dalam karyanya yang lain, yaitu Kitab pengetahuan Babasa dan Thamarät al-Mubimmah serta Syair Siti Sianah.

\subsection{Memelihara Mata}

Raja Ali Haji menempatkan mata pada urutan pertama dari anggota rubuh manusia yang terlebih dahulu harus dijaga/dipelihara agar terhindar dari berbagai keinginan negatif. Mata adalah "pintu" pertama masuknya hasrat dan keinginan negatif. Sehingga, tidak berlebihan kalau ada ungkapan "dari mana datangnya hasrat,

${ }^{37}$ Lihat, al-Ghazali, Kimia Kebahagian, ${ }^{38}$ Raja Ali Haji, Kitab Pengetahuan Bahasa, 79. 
dari mata turun ke hati". Kalau mata selalu jelalatan maka hasrat menjadi sulit untuk dibendung. Karenanya, dalam pemeliharaan mata diungkapkannya dalam Gurindam Duabelas. ${ }^{39}$

\section{Apabila terpelihara mata \\ Sedikit cita-cita.}

Pengertian memelihara mata di sini bukan dimaksudkan pemeliharaan mata secara fisiklahiri, misalnya menjaga dari sakit mata dan kebutaan. Akan tetapi, pemeliharaan mata lebih secara indera-batini, misalnya menjaga pandangan mata dari perkara dilarang agama. Dan "sedikit cita-cita" dimaksudkan Raja Ali Haji lebih bermakna pada hasrat, keinginan dan cenderung beragan-agan panjang yang kerapkali berkaitan dengan hawa nafsu negatif manusia. Andaikata mata tidak terpelihara maka manusia tidak pernah berpuas diri, tidak mensyukuri nikmat yang dianugrahkan Allah, bahkan pada gilirannya memandang remeh nikmat Allat tersebut. ${ }^{40}$

Ungkapan puitis Raja Ali Haji dalam Gurindam Duabelas di atas dielaborasi lebih lanjut dalam Kitab Pengetahuan Babasa:

Adapun "mata" hendaklah dipeliharakan dia daripada melihat barang yang diharamkan Allah Ta'ala pada syarak seperti melihat perempuan yang diharamkan melihat akan dia. Dan melihat orang berjudi dan menyabung dan barang sebagianya dari pada pekerajaan yang ditegahkan syarak. Demikian lagi melihat manusia dengan tilik pandang menghinakan dia, jika sungguh hina bangsanya daripada kita sekalipun adanya. ${ }^{41}$

Dari kutipan di atas terdapat tiga point penting yang, menurut Raja Ali Haji, dengan jelas dinyatakan bahwa haram bagi mata memandangnya. Pertama, diharamkan bagi seorang seorang lelaki memandang wanita yang bukan muhrimnya, kecuali memang akan

2

${ }^{39}$ Raja Ali Haji, Gurindam Dua Belalas,

${ }^{40}$ Dalam kaitannya ini, Rasul Allah mengajarkan, "unZ̦ urū ilā ma huwa asfala minkum wa la tanż urū ilā man huwa fawqakum fahua ajdar alla tasdarü ni'mat Alläh 'alykum." (Lihatlah terhadap orang-orang yang ada di bawahmu, dan jangalah melihat orang-orang yang ada di atasmu. Dengan demikian, kamu tidak akan menganggap enteng nikmat [yang dianugerahkan] kepadamu).

${ }^{41}$ Raja Ali Haji, Kitab Pengetahuan

Bahasa, 78. dinikahinya. Kalau terlanjur dicukupkan hanya dengan pandangan pertama, terlarang mengikuti pandangan berikutnya. ${ }^{42}$ Kedua, diharamkan seseorang melihat prilaku jahat yang menghantarkan pada kemaksiatan, seperti berbantahan dan bertikai adu fisik, dan memandang perbuatan yang dilarang agama, seperti berjudi dan menyabung ayam; dan Ketiga, diharamkan seseorang memandang sesama manusia dengan pandangan hina sebagai cerminan dari sifat sombong.

\subsection{Memelihara Telinga}

Setelah penciptaan manusia disempurnkan, Allah meniupkan (sebagian) RuhNya, dan lalu dianugrahkan pendengaran, penglihatan hati nurani (daya pengertian), tetapi sedikit sekali manusia bersyukur. ${ }^{43}$ Wujud mensyukuri angurah Allah itu, misalnya pendengaran di antaranya memelihara agar terhindar dari mendengarkan perkataan-perkataan buruk dan tercela. Dalam Gurindam Duabelas, Raja Ali Haji bertutur dengan indahnya:

\section{Apabila terpelihara kuping}

Khabar yang jahat tiada damping. ${ }^{44}$

Ungkapan Raja Ali Haji dalam bentuk puisi ini dipertegas dalam bentuk prosa dalam Kitab Pengetahaun Bahasa:

Adapun "telinga"
dipeliharakan daripada mendengarkan
daripada segala perkataan yang mungkar
seperti mendengar orang mengumpat-
umpat, karena orang yang mendengar
bersekutu dengan orang yang berkata-kata
jua adanya. Demikian lagi mendengar
daripada segala bunyian yang ditegahkan
syarak adanya."

${ }^{42}$ Sabda Rasul Allas saw.: "Jangan Anda menyusuli pandangan dengan pandangan, untuk Anda hanya yang pertama, sedang yang kedua bukan untuk Anda." (HR. Tirmidzi)

${ }^{43}$ Q.s. al-Sajadah [32]: 9. Lihat, Abdullah Yusuf Ali, adalah langkah pertama menuju berbagai kejahatan. Lihat, Abdullah Yusuf Ali, The Holy Qur'an, Texs Translation and Commentary, terj. Ali Audah (Jakarta: Pustaka Firdaus, 1993), 1066.

${ }^{44}$ Raja Ali Haji, Gurindam Dua Belalas,

2.

${ }^{45}$ Raja Ali Haji, Kitab Pengetahuan

Bahasa, 78. 
Dari pernyataan di atas nyata sekali kalau Raja Ali Haji meminta kepada penguasa dan pembesar kerajaan serta masyarakat pada umumnya untuk memelihara telinga (baca: pendengaran), sekurang-kurangnya, terhadap dua perkara. Pertama, untuk tidak mendengarkan segala perkataan yang dilarang agama, seperti mengumpat (ghibah), menghina dan memaki, dan perkataan tidak senonoh dari orang lain. Kalau tetap didengarkan segala perkara yang dilarang agama itu, menurut Raja Ali Haji, orang bersangkutan telah menjadi bagian dari orang yang mengatakan itu. Dan ia tentu juga mendapat "bagian" dosa, seperti dosa orang yang mengatakan itu.

Kedua, untuk tidak mendengarkan musik dan nyanyian mengarah kemaksiatan yang dapat membangkitkan nafsu birahi. Jenis musik dan nyanyian semacam ini, sungguh terlarang dalan ajaran Islam, seperti ditegaskan Raja Ali Haji dalam Thamarāt al-Mubimmah. ${ }^{46}$ Akan tatapi, segera harus ditegaaskan bahwa Raja Ali Haji tidak mengaramkan musik dan nyayian seacara umum. Yang diharamkannya, sekali lagi, adalah musik dan nyayian membangkitkan nafsu syahwat.

\subsection{Memelihara Lidah}

"Lidah tak bertulang", demikian pribahasa Melayu lama yang dulu kerap di ucapkan orangorang tua. Di balik pribahasa ini dapat diambil 'ibrah (pelajaran) bahwa lidah, lantaran memang tidak memiliki tulang, sedemikian lentur, sehingga dapat mengalir daripadanya berbagai kata-kata baik positif maupun negatif: berkata baik atau buruk; berkata jujur atau bohong; berkata bijak atau mengumpat; dan memberi nasehat atau makian/mencela. Sebelum mengeluarkan perkataan apakah itu positif atau negatif terlebih dahulu harus dipikirkan akibat apa yang ditumbulkannya. Perkataan yang sudah keluar dari mulut seseorang bukan lagi miliknya, tetapi sudah menjadi miliki orang yang mendengarkannya. Karenanya, sebelum melontarkan kata-kata terlebih dahulu direnungkan baik-baik karena awal dari bencana berpangkal dari mulut/lidah. Mulut/lidah dapat saja melontakan tuduhan kepada orang lain atau

46 Raja Ali Haji, Thamarāt alMuhimmah, 60. mengatakan sesuatu yang mustahil terjadi. ${ }^{47}$ Pepatah Melayu lama mengajarkan: "Mulutmu adalah harimaumu" yang setiap saat mengintai akan menerkam.

Atas dasar ini, Ali Haji menganjurkan manusia pada umumnya dan raja serta pembesar kerajaan pada khususnya agar senantiasa memelihara lidah dalam berbicara. Kalau lidah tidak dipelihara dengan baik akan mendatangkan kemudaratan bagi seseorang. Sebaliknya, kalau lidah terpelihara dengan baik akan memperoleh manfaat besar, sebagaimana diungkapkannya dalam Gurindam Duabelas:

\section{Apabila terpelihara lidah \\ Niscaya dapat dari padanya faedah..$^{48}$ \\ Dalam Kitab Pengatabuan Babasa Raja Ali}

Haji mempertegas prihal pemeliharaan lidah ini:

.... Hendaklah memelihara akan "lidah" daripada berdusta dan pembohong. Dan memelihara akan dia daripada mengumpatumpat orang dan mengadu-adu orang. Dan memeliharakan dia daripada mungkir janji yang tiada uzur yang besar dan memeliharkan dia daripada memuji-muji dan memeliharakan dia daripada menjawab dan merintangi perkataan ibu-bapanya yang hak atasnya. Demikian lagi merintangi perkataan segala ulama seperti ajaran dan nasehatnya yang hak. Dan demikian lagi memeliharakan dia daripada memaki-maki orang yang menyumpah menyeranah akan orang dan mengutuk-ngutuk akan orang, apa lagi segala perkataan yang membawa kepada kufur na'u zubillah minha. Dan lain daripada segala kejahatan lidah, seperti yang tersebut di dalam beberapa kitab-kitab tasawuf." ${ }^{49}$

Kalau ditilik perkataan Raja Ali Haji di atas begitu banyak cela-cela yang menyebabkan manusia untuk tidak dapat waspada dalam memelihara lidahnya (perkataan). Akibatnya,

$$
47 \text { Rasulullah s.a.w. bersabda : }
$$

"Cobaan itu sumbernya berasal dari lisan, andaikata ada seseorang menuduh orang lain bahwa ia menyusu kepada anjing, maka (menurut lisan) hal itu bisa saja terjadi." (Hadist riwayat Al Khathib dari Ibnu Mas'ud).

${ }^{48}$ Raja Ali Haji, Gurindam Duabelas, 2.

${ }^{49}$ Raja Ali Haji, Kitab Pengetahuan

Bahasa, 78 
manusia terancam tergelincir pada perkataan yang salah dan tercela. Berdusta yang sedemikian besar dosanya, sehingga Rasul Allah saw. menyetarakan dosanya dengan menyekutukan Allah (al-shirk bi Allah) dan durhaka kepada (kedua) orang tua. ${ }^{50}$ Dengan kata lain, sedemikian pentingnya memelihara lidah dari perkataan bohong dan sumpah palsu, sampai-sampai Rasul Allah saw. memasukkan sebagai dosa besar beriringan dengan mempersekutukan Allah dan durhaka kepada orang tua.

Bergunjing sebagai bagian dari aktivitas lidah sedemikian nistanya, sehingga Allah mengilustrasikan ibaratnya sama dengan memakan bangkai saudara sendiri yang tentu saja tidak berkenan karena merasa jiijk. Begitu pula, lidah harus dipelihara untuk tidak membantah nasehat orang tua; dan menentang ajaran agama yang disampaikan ulama; atau mencaci-maki dan mengutuk/menyumpah orang lain (sumpah seranah). Untuk menjaga perbuatan tercela atau kejahatan yang disebabkan oleh lidah ini, karenanya, Raja Ali Haji mengajak masyarakatnya, khususnya penguasa dan pembesar kerajaan untuk mempelajarinya dari kitab-kitab tasawuf.

Dalam al-Qur'an orang beriman diseru agar bertakwa kepada Allah dan "berkatalah (selalu) langsung dengan kata-kata yang benar." Sejalan dengan ini, Rasul menganjurkan kalau seseorang beriman kepada Allah dan hari akhirat hendaklah ia mengormati tetangga dan memuliakan tamu serta "qul al-khayr aw li yasmul" (hendaklah ia berkata baik-baik atau diam). Rasul Allah saw. mengingatkan diam adalah ibadah paling mudah dilaksanakan. Selain itu, memelihara lidah dari mengumpat sedemikan penting, sehingga Rasul Allah saw. mengingkari orang bersangkutan "bukanlah golonganku". Sedemikian pentingnya memelihara lidah dari kebiasaan mencela dan melaknat, sehingga kalau

\section{Rasul Allah saw. bersabda:} "Maukah kalian kuberi tahu dosa yang paling besar? Yaitu, menyekutukan Allah dan durhaka kepada kedua orang tua." Waktu itu Nabi saw. sedang berbaring, lalu beliau duduk seraya bersabda: "Ketahuilah, juga kata-kata dusta." Lihat, al-Ghazali, Kitab al-Arba'īn fĩ Usūl alDìn [Jalan Mudah Menggapai Hidayah, terj. Rojaya] (Bandung: Pustaka Hidayah, 2008), 108. tidak mampu memeliharanya, Rasul Allah saw. menyatakan bukanlah orang yang beriman.

Sebaliknya, sebaik-baik mukmin adalah orang yang dapat menyelamatkan orang mukmin lainnya dari lidah dan tangannya. ${ }^{51}$ Dengan nada seirama, Rasul Allah saw. bersabda: "Sebaik-baike pemberian ialah perkataan yang benar yang engkau telah mendengarnya kemudian engkau sampaikan kepada saudaramu yang muslim lalu engkau ajarkan kepadanya. ${ }^{{ }^{52}}$ Rasul Allah saw. menjanjikan bahwa Allah swt. akan menganugerahkaan kebaikan dunia dan akhirat di antaranya terhadap orang yang lidahnya senantiasa berzikir (ingat pada Allah). ${ }^{53}$ Kemudian, Rasul Allah saw. mempersilahkan seseorang masuk surga dengan selamat kalau mematuhi sejumlah perintah di antaranya "Baikkanlah perkataan,...". ${ }^{54}$

Seseorang mengatakan perkataan yang diridhai-Nya maka Allah mengakat baginya satu derajat keluruhan. Sebaliknya, seseorang mengatakan perkataan yang dimurkai-Nya maka Allah menjerumuskan ke dalam neraka. ${ }^{55}$

${ }^{51}$ Rasul Allah saw bersabda: "Sebaikbaik mukmin (tentang) keislamannya ialah orang yang dapat menyelamatkan orang Islam dari lidahnya dan tangannya. Dan sebaik-baik mukmin (tentang) keimanannya ialah orang yang paling baik perangainya dan sebaik-baik muhajirin ialah orang berhijrah dari apa-apa yang dilarang Allah padanya dan sebaik-baik jihad ialah orang yang berjihad pada jalan Allah."

${ }^{52} \mathrm{HR}$. Thabrani dari Ibnu Abbas.

${ }^{53}$ Rasul Allah saw. bersabda: "Empat macam orang yang diberikan kepadanya keempat hal berikut ini, maka sesungguhnya ia telah dianugerahi kebaikan dunia dan akhirat, yaitu : lidah yang selalu berzikir, hati yang selalu bersyukur, diri yang sabar menerima cobaan, dan isteri yang tidak berkhianat pada dirinya dan tidak pada hartanya. ( HR. dari Ibnu Abbas).

${ }^{54}$ Rasul Allah saw. bersabda: "Baikkanlah perkataan, tebarkanlah salam, hubungkanlah silaturrahim, shalatlah di malam hari sewaktu manusia masih tidur, kemudian masuklah kamu ke dalam surga dengan selamat." (HR. Ibnu Hibban dari Abu Hurairah).

${ }^{55}$ Rasul Allah saw. bersabda : "Sesungguhnya seorang hamba yang mengatakan perkataan yang diridhoi Allah sekalipun perkataannya itu tidak diperhatikan, maka Allah mengangkat satu derajat keluhuran untuknya. Dan sesungguhnya seseorang hamba yang mengatakan perkataan yang membuat Allah 
asulullah Saw. bersabda tentang sesuatu yang menyebabkan orang ke dalam neraka, beliau menjawab, "Mulut dan kemaluan". ${ }^{56}$ Begitu pula, seseorang akan menjadi penghuni neraka ketika lidah meraka menjalin kepalsuan bahwa segala yang baik untuk mereka, sementara mereka menghubungkan kepada Allah segala yang mereka tidak sukai. Sesungguhnya mereka tidak bisa mengelak karena lidah bersama dengan anggota tubuh lainnya akan menjadi saksi di hari akhirat atas perbuatan jahat yang mereka lakukan di dunia.

\subsection{Memelihara Tangan}

Rasul Allah saw. bersabda: "Muslim itu adalah orang yang muslim lainnya selamat dari lidah dan tangannya...." Raja Ali Haji menasehati agar tangan dipelihara jangan sampai "ringan tangan", sehingga orang lain selamat dari tangan kita. Sekiranya kita tidak mampu memelihara tangan, dan orang lain tidak selamat karennya, menurut sabda Rasul Allah saw., berarti kita bukanlah seorang muslim. Sebaliknya, kita harus memelihara tangan kita agar jangan "berat tangan" dalam melakukan kebaikan, misalnya menolong orang lain. Dalam Gurindam Duabelas pemeliharaan tangan diutarakan dalam bentuk puitis:

tangan

Bersunggub-sungguh engkau memeliharakan

daripada segala berat dan ringan.

Sementara pemeliharaan tangan dalam bentuk prosa Raja Ali Haji sebutkan dalam Kitab Pengetabuan Babasa:

Adapun "tangan" hendaklah memeliharakan dia daripada mencapai dan memegang barang yang ditegahkan syarak seperti mencuri dan merampas, menyamun harta benda orang dengan tiada sebenarnya. Dan demikian lagi hendaklah peliharakan dia daripada memukul dan memalu orang dengan tiada sebenarnya adanya."

Pemeliharaan tangan secara indera-lahiri tidak relavan di sini, misalnya pemeliharaan agar tangan terhidar dari luka sakit atau terpotong sekalian. Dalam pandangan fisik-lahiri boleh jadi tangan seseorang "pontong", tetapi karena tidak

murka sekalipun perkataannya tidak diperhatikan maka ia akan dijerumuskan (dicampakkan) ke dalam neraka Jahannam." ( Hadist Riwayat Imam Ahmad).

${ }^{56}$ HR. Tirmidhi. terpelihara secara fisik-batini maka orang bersangkutan disebut "panjang tangan" (suka mencuri [mengambil milik orang lain baik secara diam-diam] ataupun merampas [mengambil milik orang lain secara terang-terangan]). Raja Ali Haji juga mengingatkan agar memelihara tangan jangan sampai "ringan tangan", misalnya tanpa sebab yang dapat dibenarkan dengan mudah memukul orang lain.

Pemeliharaan tangan dalam perspektif indera-batini menjadi sangat penting bila dikaitkan dengan perhitungan Allah di akhirat, yaitu pada hari di mana orang-orang tidak dapat berbohong (mengingkari perbuatan-perbuatan jahat) dan menutup-menutupi kesalahannya yang pernah dilakukan di dunia. Pada hari perhitungan di padang mahsyar mereka tidak mungkin mengelak karena tangan-tangan akan menjadi saksi atas segala perbuatan yang telah dilakukannya di dunia. Allah menyebutkan dalam al-Qur'an, "al-yawma nakhtim 'alà afwāhibim wa tukallimuna aydībim" (pada hari ini Kami sumbat mulut mereka dan tangan-tangan mereka berkata kepada Kami). ${ }^{57}$

\subsection{Memelihara Kaki}

Raja Ali Haji menasehatkan agar kaki dipelihara untuk tidak melangkah kepada perbuatan maksiat yang mendatangkan kerugian, sebagaimana ia tuturkan dangan indah dalam Gurindam Duabelas:

Hendaklah memelihar kaki

daripada berjalan yang membawa rugi.

Raja Ali Haji menegaskan kembali pemeliharaan kaki dalam Kitab Pengetahuan Bahasa:

Adapun "kaki" hendaklah peliharakan dia daripada berjalan pada pekerajaan maksiat. Maka yaitu amat banyak, tiadalah dapat dinyatakan habis pada kita yang simpan ini. Lagipula bukannya maksud di sini membanyakkan dia. Syahdan setengah daripada memeliharakan kaki daripada pergi-pergian kepada tempat yang ditegahkan syarak seperti segala tempat yang maksiat dan pergi kepada tempat raja yang zalim dengan tiada tujuan. ${ }^{58}$

Dari dua kutipan di atas, sepertinya antara Gurindam Duabelas dan Kitab Pengetabuan Bahasa

$$
\begin{aligned}
& { }^{57} \text { Q.s. Yāsīn [36]: } 65 . \\
& { }^{58} \text { Raja Ali Haji, Kitab Pengetahuan }
\end{aligned}
$$

Bahasa, 78 
"berkalaborasi" dalam soal memberi nasehat prihal memelihara kaki. Kedua karya Raja Ali Haji ini "sepakat" agar kaki dipelihara supaya tidak ditimpa kerugian baik di dunia terlebih lagi di akhirat. Dalam Kitab Pengetabuan Bahasa, penulisnya menganjurkan supaya kaki dipelihara untuk tidak mendatangi tempat-tempat maksiat, tempat-tempat terlarang oleh ajaran agama, termasuk mengunjungi kediaman raja yang zalim dengan tanpa tujuan.

Sekiranya kaki tidak dipelihara mengunjungi tempat-tempat maksiat, umpamanya tempat perjudian, pelacuran masing-masing akan melahirkan kerugian berupa kebangkrutan dan tercemarnya nama baik (kehormatan) di dunia. Kerugian paling hakiki akan diderita di akhirat atas perbuatan-perbuatan dosa tersebut. Perbuatan-perbuatan dosa itu akan dimintai pertanggungjawabanya di hari perhitungan, dan kaki akan menjadi saksi atas perbuat maksiat yang dilakukan di dunia ini. Al-Qur'an menyebutkan: "Wa tashadu arjulubum bimā keānù yaksibūn" (dan kaki-kaki mereka memberikan kesaksian apa yang telah mereka lakukan). ${ }^{59}$ Pada ayat lain dengan redaksi yang sama al-Qur'an menyebutkan bahwa mereka tidak bisa mengingkari kejahatankejahatan yang mereka perbuat di dunia lantaran kaki besarta anggota tubuh lainnya akan menjadi saksi di hari akhirat.

\subsection{Memelihara Alat Kelamin}

Menahan pandangan dan memelihara kehormatan merupakan perintah Allah baik kepada seorang lelaki (mu'min) maupun kepada wanita (mu'minah). ${ }^{60}$ Kemampuan memelihara kehormatan (kemaluan/alat kelamin), selain kepada pasangan, sehingga tidak mendekati dan terhadar dari zina (sungguh itu perbuatan keji [fähisha], dan jalan yang buruk [wa säa sabila] $)^{61}$ merupakan salah satu "karakteristik" seorang mukmin yang beruntung. ${ }^{62}$ Bahkan, menurut sabda Rasul Allah saw., salah satu penyebab utama masuknya seseorang ke surga karena kemampuannya memelihara kehormatan di

\footnotetext{
${ }^{59}$ Q.s. Yāsīn [36]: 65.

${ }^{60}$ Q.s. al-Nūr [24]: 30-31.

${ }^{61}$ Q.s. al-Isrā' [17]: 32.

${ }^{62}$ Q.s. al-Mu'minūn [23]: 1-11.
}

antara pangkal "kedua pahanya". ${ }^{63}$ Sebaliknya, ketidakmampuan seseorang memelihara kehormatan dengan memperturutkan hawa nafsunya menjadi salah satu penyebab kebinasaannya.

Raja Ali Haji mengatakan bahwa andaikata alat kelamin senantiasa terjaga gairah dari hubungan intim yang terlarang. Dalam Gurindam Duabelas, ia mengungkan: Anggota tengah hendaklah ingat disitulab banyak orang yang bilang semangat.

Dengan ungkapan berbeda, dalam Kitab Pengetabuan Bahasa, Raja Ali Haji menyebutkan:

Adapun "zakar" pula hendakalah peliharakan dia daripada mengerjakan segala yang diharamkan oleh syarak seperti berzinah dan berliwath atau mengerjakan binatang sekalipun. Demikian lagi merancap itupun haram jua adanya.

Dari kutipan di atas Raja Ali Haji menasehatkan agar memelihara alat kelamin dari prilaku seksual yang dilarang agama, seperti berzina. Begitu pula, ia memperingatkan agar memelihara kemaluan dari prilaku seksual menyimpang yang tentu saja hukumnya adalah haram, yatu hubungan seksual dengan binatang dan perilaku "homoseksual", seperti dilakukan umat zaman Nabi Luth.

Raja Ali Haji mengingatkan agar memelihara alat kelamit dari "birahi" yang diartikannya: "Yaitu kehendak seseorang akan sesuatu yang sangat keras ingin nafsunya sekira-kira tiada hilang daripada yang dikehendakinya itu tiap-tiap masa dan ketika. Maka apabila berkelakuan demikian adalah ia menjadi penyakit yang besar kepada hati..." ${ }^{64}$ Selanjutnya, ia menyatakan bahwa kalau sekiranya orang tersebut tidak mampu memelihara dan mengendalikan hawa nafsu (birahi)nya itu, maka "memakanlah ia kepada

${ }^{63}$ Rasul Allah s.a.w. bersabda : "Barang siapa yang dipelihara Allah dari kejahatan apa yang di antara kumis dan janggotnya dan yang di antara dua kakinya, pasti masuk surga.(HR Tirmidzi dari Abu Hurairah).

Bahasa, 79. 
akal api birahi" yang kemungkinan bisa berakibat parah, misalnya sampai sakit, gila dan bahkan meninggal dunia. ${ }^{65}$

\subsection{Memelihara Hati}

Memelihara hati, sebagaimana telah dipaparkan di depan, menjadi sangat penting karena hati adalah "raja" dalam diri manusia. Tepatnya, Raja Ali Haji mengukir dalam Gurindam Duabelas dengan indahnya:

\section{"Hati itu kerajaan di dalam tubuh}

\section{jikalau zalim segala anggotapun rubuh."}

Dalam Kitab Pengatehauan Bahasa Raja Ali Haji menasehatkan, khususnya penguasa sebagai raja dalam masyarakat, agar memelihara hatinya dari sifat-sifat tercela:

.... hendaklah peliharakan dia daripada takbur yakni membesarkan diri, melihat dirinya lebih semata-mata baik pada bangsa atau pada rupa atau pada harta pada ilmu. Maka yaitu tertegah oleh syarak. Dan demikian lagi hendaklah peliharakan dia daripada dengki akan sesorang yang mendapat nikmat. Dan hendkalah peliharakan dia daripada segala kejahatan hati seperti yang tersebut di dalam beberapa kitab karangan ulama yang besar-besar, istimewa pula di dalam al-Qur'an dan di dalam Hadith. ${ }^{66}$

Dari kedua karya Raja Ali Haji di atas tampak bahwa hati memiliki arti penting dan kedudukan yang tinggi dibanding dengan anggota badan lainnya. Kerenanya, ia meminta kepada penguasa dan pembesar kerajaan secara khusus agar memelihara hati dari berbagai penyakit, utamanya sifat zalim dan sombong serts dengki. Ketiga penyakit hati ini sedemikian berbahaya, kalau penyakit menimpa hati maka segala anggotapun rubuh. Artinya, kalau penguasa dn pembesar kerajaan memiliki sikap zalim dan sombong maka tinggal menunggu masanya kerajaanpun rubuh. (Pada bagian ini tidak diulas secara detail tentang pemiliharaan hati sebab pada bagian terdahulu telah di uraikan cukup panjang lebar).

\section{Pendekatan Indera-Lahiri}

${ }^{65}$ Raja Ali Haji, Kitab Pengetahuan Bahasa, 221.

Bahasa, 79.
Pendekatan indera-fisik ini bersifat dan berorientasi pada kesehatan ilmu kedokteran. Menurut Raja Ali Haji, sebelum melakukan "pengobatan" terhadap penyakit yang sedang menimpa badan, ada beberapa usaha "pencegahan" yang dapat diupayakan oleh penguasa agar badan tetap selalu sehat dan tampil prima. Kesehatan bagi seorang penguasa dan pembesar kerajaan adalah sangat penting bagi keberlangsungan pemerintahan dalam menjalankan amanah dan wewenang yang dimilikinya.

Kalau kita rujuk kembali, sebagaimana telah disebutkan sebelumnya, bahwa salah satu persyaratan seorang penguasa adalah memiliki integritas fisik yang baik/sempurna, khususnya indra-indra tertentu, seperti mata, telinga dan tubuh penting lainnya. Dari persyaratan tentang integritas fisik, sepertinya Raja Ali Haji mengisyaratkan agar tidak "terlanjur" menobatkan raja yang menyandang cacat inderafisik. Untuk itu, Raja Ali Haji memberikan petunjuk dan menyarankan agar penguasa dan pembesar kerajaan menjaga kesehatan dengan cara menjaga pola hidup sehat, seperti olah raga dan istirahat yang cukup serta menjaga pola makan agar tetap sehat dan tidak mudah terjangit penyakit.

\subsection{Waktu Makan dan Minum}

Raja Ali Haji menyarankan, hendaklah makan dan minum secara teratur dan tidak berlebihan serta, sesuai dengan tuntunan Rasul Allah saw., janganlah makan sewaktu masih kenyang atau berhenti makan sebelum kenyang. Dan ketika makan hendaknya dikunyah dengan hancur sebelum ditelan. Ia mengingatkan bahwa hendaklah makan makanan dan rempah-rempah dengan menyesuaikan kondisi (tabiat) badan dengan situasi (tabiat) alam ${ }^{67}$ yang selalu

${ }^{67}$ Kondisi (tabiat) tubuh manusia dan situasi (tabiat) alam, menurut Raja Ali Haji, terdiri dari empat anasir, yaitu: "panas-kering; panas basah; sejuk kering; dan sejuk basah." Untuk mengetahui penjelasan tentang masalah ini, Raja Ali Haji meminta kepada penguasa untuk bertanya kepada orang yang ahli tentang rempah-rempah dan gizi kepada tabib (dokter); tetang mata hari dan peredarannya kepada yang ahli falak. 
mengalami perubahan dengan berpindahnya "segala buruj" (gugusan bintang) yang ada di tata surya. ${ }^{68}$

\subsection{Waktu Tidur}

Dalam menjaga kesehatan seseorang memerlukan istirahat yang cukup. Dan istirahat yang paling baik, menurut Raja Ali Haji, adalah dengan tidur yang wajar dan cukup. Sebaliknya, ia mencela seseorang yang kebanyakan tidur, terlebih-lebih bagi seorang penguasa dan pembesar kerajaan. Ia merinci bahwa tidur yang normal tidak lebih dari delapan jam pada malam hari. Dan kalaupun harus tidur siang hari, sebaiknya kurang lebih satu jam. Kemudian, ia mengingatkan memperbanyak tidur menyianyiakan waktu (umur) dan akan menghilangkan cahaya muka. ${ }^{69}$

\subsection{Waktu Hubungan Badan}

Pada pandangan Raja Ali Haji, hendaklah melakukan "jimak sesuai dengan waktunya, yaitu ketika datang syahwat." Ketika melakukan, saran Raja Ali Haji, "hendaknya dengan tertib dan adab seperti ajaran-ajaran yang disunatkan oleh Nabi Șallallahu 'Alaibi Wasallam'. ${ }^{70}$ Lebih lanjut, Raja

Selanjutnya, Raja Ali Haji menyatakan, “.... Dan patut raja-raja dan orang-orang besar mengethui ilmu ini supaya ia membezakan badannya dengan makanan dan dengan rempah dan dengan tabi'at pasal-pasal dunia ini, supaya diobatkannya badan dengan makanan dan dengan pasalnya supaya menjadi sehat dan 'afiat. Dan hendalah makan dan minum dengan adabnya, seperti di dalam Kitab al-Adab Adab al-'Aqli tuntutlah olehmu." Lihat, Raja Ali Haji, Thamarāt al-Muhimmah, 45-47.

68 Raja Ali Haji, Thamarāt alMuhimmah, 47.

69 Raja Ali Haji, Thamarāt alMuhimmah, 47.

${ }^{70}$ Raja Ali Haji menyebutkan adab Nabi Muhammad saw. melakukan hubungan seks, misalnya dianjurkan suami-istri jangan telanjang bulat (bugil) seperti binatang, jangan pula memandang kepada alat kelamin lawan jenis. Selain itu, apabila laki-laki "anzal" terlebih dahulu jangan ditarik alat kelaminnya "biar selesai anzalnya perempuan itu, apabila selesai
Ali Haji mengingatkan, bahwa "melakukan jimak dengan malampaui adat sebab mengikuti hawa nafsu" dapat mempercepat proses penuaan; mendatangkan "penyakit lemah sendi-sendi, istimewa pula jika mempunyai tabiat sadwa, yakni 'sejuk kering' yaitu lebih segera memberi mudharat". ${ }^{71}$

\subsection{Waktu Olah Raga}

Berolah raga (atau "menggerak-gerak tubuh" istilah Raja Ali Haji) penting bagi penguasa. Dengan berolah raga akan memperlancar peredaran darah. Sebaliknya, kalau badan jarang bergerak darah sulit untuk mengalir. Dengan begitu, kalau peredaran dari tidak lancar penyakit mudah menyerang tubuh seseorang. Bahkan ia menyebutkan olah raga sebaiknya dilakukan setiap hari dengan kadar yang patut. ${ }^{72}$

\subsection{Waktu Menghirup Udara}

Raja Ali Haji menyarankan agar menyegarkan dan menyehatkan badan dengan hawa dan angin yang sepoi-sepoi. Menurutnya, udara yang segar adalah setelah waktu shalat subuh. Sedangkan angin yang baik adalah "angin lemah lembut daripada pihak masyrik". ${ }^{73}$

\section{Penutup}

Kalau dicermati, Raja Ali Haji selalu menganjurkan kepada penguasa untuk mengingat dan merenungkan keberadaan manusia pada kehidupan eskatologis (kehidupan kedua di akhirat). Maka pada bagian akhir wazifah dalam Muqaddimah fi al-Intizām, Raja Ali Haji menyarankan kepada penguasa, sembari melaksanakan tugasnya sebagai kepala pemerintahan, agar juga tidak lupa menjalankan tugas 'ubūdiyah sebagai hamba Allah serta senantiasa mengingat kematian dan merenungkan

hendaklah dibasuh zakar kita itu dulu jikalau kita hendak jima' sekali lagi pun." Lihat, Raja Ali Haji, Thamarāt al-Muhimmah, 48.

${ }^{71}$ Raja Ali Haji, Thamarāt al-

Muhimmah, 48.

${ }^{72}$ Raja Ali Haji, Thamarāt al-

Muhimmah, 49.

${ }^{73}$ Raja Ali Haji, Thamarāt al-

Muhimmah, 49. 
kehidupan di akhirat. ${ }^{74}$ Persisnya, ia menasehatkan secara khusus kepada adik sepupunya, Raja Ali bin Ja'far YDM VIII Riau, ungkapnya:

.... jangan sekali-kali lupa akhirat itu meskipun ada dapat kesukaan dan kedukaan, kenangan juga akhirat itu. Jikalau berat sekalipun kepada hati memikirkan akhirat itu, gagahkan juga memikirkan dia. Karena ingatkan akhirat itu pohon segala kebajikan dan kemenangan, adanya. ${ }^{75}$

Pada bagian lain dalam Kitab Pengetahuan Bahasa Raja Ali Haji meminta kepada masyarakatnya agar memahami eksistensi kehidupan (hari) akhirat lebih baik dan utuh dengan membaca dan memahamai al-Qur'an dan Hadith Nabi disertai segala tafsirnya. Kata Raja Ali Haji selanjutnya, "Maka yaitu sangatlah banyaknya dengan berulang dalam beberapa tempat daripada ayat di dalam Qur'an mengkhabarkan hal ikhwal akhirat itu." Selain itu, ia menyarankan, "maka hendaklah engkau baca akan segala kitab-kitab yang panjangpanjang....," ${ }^{76}$ sebagaimana tertera dalam kitabkitab ulama pada masa lalu.

Bagi Raja Ali Haji, mengingat Allah adalah pangkal "hikmah" (ra's al-hikmah rikr Alläb). Zikir kepada Allah dan pada gilirannya Allah hadir (omnipresent) dalam diri akan menimbulkan perunungan dan kesadaaran bahwa kita berasal dari Allah dan akan kembali kepada Allah (innā li Allāh wa innā ilaīh räjíün). Dari zikir kepada Allah inilah menimbulkan "zikir-zikir" berikutnya, yaitu: kematian dan hari akhirat. Untuk kembali kepada Allah meniscayakan terlebih dahulu melewati "pintu" kematian; dan untuk bertemu dengan Allah meniscayakan terlebih dahulu berada dalam alam akhirat (surgawi). Dengan mengingat kematian, menurut

${ }^{74}$ Rasul Allah saw. bersabda: "Perbanyaklah mengingat mati karena hal itu akan menghapus dosa dan menghilangkan perasaan cinta dunia dalam hatimu." Pada lain kesempatan, Rasul Allah saw. pernah ditanya, "Siapakah manusia yang paling berakal dan paling bijaksana?" Rasulullah menjawab: "Orang yang paling berakal adalah yang paling banyak mengingat mati. Sementara orang yang paling bijak adalah orang yang paling baik persiapan. Dia akan mendapat kemulian di dunia dan di akhirat." Lihat, Al-Ghazali, Al-Tỉb al-Masbūk fī Nașhiat al-Mulūk, Etika Berkuasa Nasehat-nasehat Imam alGhazali, terj. Arief B. Iskandar (Bandung: Pustaka Hidayah, 1988), 73-74.

${ }^{75}$ Raja Ali Haji, Muqaddimah fī al-Intiẓ ām, 13.

${ }^{76}$ Raja Ali Haji, Kitab Pengetahuan Bahasa, 34.
Raja Ali Haji, seseorang disadarkan untuk melakukan "bakti" kepada Allah, yaitu menjalankan perintah-Nya dan meninggalkan larangan-Nya. Selain itu, mengingat kematian akan membuat seorang sadar makna kehadirannya di dunia yang fana ini, sekaligus mempersipkan bekal bagi kehidupan di akhir yang kekal. Selanjutnya, menurut Raja Ali Haji, hari akhirat itu nyata dan pasti, tentu saja bagi orang yang tidak buta hati. Pendapat Raja Ali Haji ini terambil dari bagian akhir Gurindam Duabelas yang digubah dengan indahnya:

$$
\begin{aligned}
& \text { Ingatkan dirinya mati } \\
& \text { Itulah asal berbuat bakti. } \\
& \text { Akbirat itu terlalu nyata } \\
& \text { Kepada bati yang tidak. buta }
\end{aligned}
$$

\section{DAFTAR PUSTAKA}

Al-Ghazali. (2006). Bidāyah al-Hidāyah Jakarta:Menara.

Ali, Abdullah Yusuf. (2004). The Meaning of theHoly Quran, Maryland: Amana

Publications.

Ali Haji, Raja, (1986). Kitab Pengetahuan Bahasa,Pekanbaru: Badan Penelitian dan Pengkajian Melayu Dept. P dan K, .(1304) Muqaddimah fì alIntiz̄ām al-Wazāif al-Mulk Khusūsan ilā Mawlāna wa Șāhibinā Yang Dipertuan Muda Raja Ali al- Mudabbir li al-Bilād alRiauwiyyah wa Sāir Dāirat, Lingga: Pejabat Kerajan Lingga, .(1973.). Silsilah Melayu-Bugis, Kuala Lumpur: Pustaka Antara. .(1304.) Thamarāt al-Muhimmah, Lingga: Pejabat Kerajaan Lingga.

.(1982.). Tuhfat al-Nafîs, Transliterasi oleh Inche Munir bin Ali, Singapura: Malaysia Publikasi Ltd., 1965.

, Hadiah Berharga (Tuhfat al-

Nafis), ed. Virginia Matheson dan Barbara W. Andaya, Kuala Lumpur: Oxford University Press.

.( 1997). Tuhfat al-Nafis Sejarah

Melayu Islam, Virginia Matheson ed., Kuala Lumpur: Dewan bahasa dan Pustaka. 
Alimuddin Hassan Palawa: Pemeliharaan diri...

.(1982). Tuhfat al-Nafís, (ed.Virginia Matheson), Kuala Lumpur: Fajar Bakti.

(1998). Tuhfat al-Nafìs (ed.Virginia Matheson), Kuala Lumpur: Yayasan Karyawan dan Dewan Bahasa dan Pustaka

.(1983). Syair Siti Sihanah, Pulau Penyengat: Yayasan Kebudayaan Indra Sakti, Koleksi Naskah No. A.

. (1989) Syair Abdul Muluk, Pekanbaru: Penelitian dan Pengkajian Kebudayaan Nusantara Depdikbud,

Hamka. (1983). Tafsir Al-Azhar, Juz XXIX Jakarta: Pustaka Panjimas.

Sham, Abu Hassan. (1987) 'Karya-Karya Yang Berlatarbelakang Islam dari Pengarang Melayu-Johor Sehingga Awal Abad Kedua Puluh", dalam Tradisi Johor-Riau: Kertas Kerja Hari Sastra1983, Kuala Lumpur: Dewan Bahasa dan Pustaka. . (1993) Puisi-Puisi Raja Ali Haji,

Kuala Lumpur: Dewan Bahasa dan

Pustaka.

Riau,Kuala Lumpur: Perpustakaan Negeri Malaysia.

Ya'qub, Ali Mustafa.( 2008) Hadis-hadis Bermasalah. Jakarta: Pustaka Firdaus. 